\title{
EFFECTS OF ACADEMIC QUALIFICATIONS ON MALAYSIAN ENGLISH LANGUAGE TEACHERS' SUBJECT MATTER KNOWLEDGE OF LITERARY DEVICES
}

\author{
Manickavasagar Govindasamy and Jariah Mohd. Jan \\ University of Malaya
}

\begin{abstract}
Previous studies in the West have shown teachers who are academically qualified in specific subjects are able to teach better than those with degrees in non-specific subjects (Goldhaber and Brewer, 1996). Such studies within the local context are limited. As such, this study examines the effects of academic qualifications on the subject matter knowledge of literary devices among secondary school English language teachers in a northern district in Malaysia. The analysis revealed that academic qualifications had significantly influenced the subject matter knowledge of literary devices and such knowledge differ significantly among the English major and English minor, TESL and KPLI or Postgraduate Teaching Programme English language teachers. Specifically, the English major language teachers had better subject matter knowledge of literary devices than the non-English major language teachers. The TESL teachers were better than the non-TESL teachers in their subject matter knowledge of literary devices. The subject matter knowledge of literary devices amongst the KPLI English language teachers was lower compared to the non-KPLI language teachers.
\end{abstract}

KEYWORDS: ACADEMIC QUALIFICATIONS, SUBJECT MATTER KNOWLEDGE, LITERARY DEVICES, TEACHING OF ENGLISH AS SECOND LANGUAGE (TESL), POST-GRADUATE TEACHING PROGRAMME IN ENGLISH (KPLI)

\section{Introduction}

The Ministry of Education (MoE) of Malaysia introduced the literature in English component in 2000 that was subsequently incorporated into the English language paper at secondary school level. The Literature Component intends "to show an awareness of how language is used to achieve particular purposes" (MoE, 1999:13) to learners. The introduction of the Literature Component is in accordance with the importance given to the study of English as a second language in other parts of the world where literary works have been included for the development of language. The renewed interest in the study of literature exposes learners to different linguistic varieties such as lexical, syntactical items, subtle and complex forms of grammar and idiomatic expressions (Coolie and Slater, 1987). In the Malaysian context where English is the second language, the Literature Component has a valuable place by virtue of its indisputable functions that explore the resources of the language. In order to enhance the language aspect, literature has been introduced "to acquaint learners with the manner in which literary works in English use language to convey special meanings" (Widdowson, 1975:78).

The current emphasis on language in the Literature Component requires English language teachers to equip themselves with subject matter knowledge of literary devices and not just with pedagogical 


\section{EFFECTS OF ACADEMIC QUALIFICATIONS ON MALAYSIAN ENGLISH LANGUAGE TEACHERS' SUBJECT MATTER KNOWLEDGE OF LITERARY DEVICES}

strategies (Wong, 2003). Therefore, "English language teachers need to have in-depth knowledge of their subject area to allow them to be convincing" in the explanation of the various literary texts

(Fauziah Ahmad \& Ura Pin, 2007:64). When language teachers are familiar with the different literary devices, they can understand and explain the text by not only focusing on "what the text means, but also how it comes to mean" (Short, 1996:6). This method of text analysis leads to the discovery of "layers of possible meanings and any irregular linguistic patterns within a test" that may not be detected if other approaches are used (Clark \& Zyngier, 2003:340).

Presently, literature in English is taught by two categories of English language teachers in Malaysian secondary schools. The first category has formal language qualifications and consists of three groups. The first group consists of single major English language teachers with degrees in English language or/and literature per se and has studied the subject in-depth. The second group is the English minor language teachers who have majored in other subjects but choose courses in literature as electives at minor level. The third group consists of those who have obtained degrees in the Teaching of English as a Second Language (TESL) from public and private institutions of higher learning. The main emphasis in their degree programme is the pedagogical approach to teach the English language and courses in English literature have been included.

The second category of English language teachers form the fourth group and have informal language qualifications. They have majored in other subjects but not English and have undergone a one-year Post-graduate Programme in the Teaching of English as a Second Language, which is also known as Kursus Perguruan Ijazah Lanjutan (KPLI/Post-graduate Teaching Programme) (Khan, 2003). The main objective of this programme is to provide sufficient pedagogical knowledge to teach the English language in secondary schools. The Literature Component included in this programme deals with appreciation, understanding language use and critical evaluation of issues in literary texts (Khan, 2003). These programmes can be helpful as they can enhance the subject matter knowledge of teachers in their instructional practices (Little and McLaughlin, 1993; Varella, 2000).

In Malaysia, English Language teachers are graduates from public and private institutions of higher learning. These institutions have the academic freedom to select their courses in English literature, language and linguistics. Based on the educational background, these English language teachers have a diversity of academic qualifications. As such, it is difficult to assume they have equally comparable subject matter knowledge of literary devices and literature to teach the different genres in the Literature Component. At the same time, there is also a lack of local research based on the subject matter knowledge of literary devices of English language teachers.

Studies in the West have shown a lack of consensus in the subject matter knowledge among those who have a major or minor in a particular subject. Research conducted at the National Centre for Research on Teacher Learning at Michigan State University show that majoring in a subject is insufficient to be knowledgeable in it (1980). Kennedy (1991:14) further supports that "majoring in an academic subject in college does not guarantee teachers will have the kind of subject matter knowledge they need for teaching." Research findings on graduates who had undergone the "alternative quick-entry" courses showed they were unable to compete with those who had completed the traditional programmes in specific subjects (Grossman, 1989; Darling-Hammond, 2000). It was pointed out that conceptual differences existed in the subject matter knowledge between the "alternative quick entry" and those who had followed the traditional programmes (Newton-Newton, 1999). In addition, research by Wayne and Youngs (2003) commenting on the subject matter knowledge of teachers indicated that 'in-field' teachers were more effective than 'out-of- field' teachers. 


\section{EFFECTS OF ACADEMIC QUALIFICATIONS ON MALAYSIAN ENGLISH LANGUAGE TEACHERS' SUBJECT MATTER KNOWLEDGE OF LITERARY DEVICES}

Norrel (1994) supporting Porter and Borphy (1988) has indicated that subject matter knowledge was essential because it influenced the 'what' and 'how' teachers presented their subjects to learners. Teachers had to be well equipped with their subject matter to make well informed decisions on what and how to teach and the types of materials that could be used in their lessons (Lempert, 1988). Goldhaber and Brewer (2000) and Hattie (2003) stressed that teachers with subject specific degrees had displayed better understanding of their subject matter than others. However, these claims were refuted by Martin et al. (2000) and Wenglinsky (2000) who found that majoring in a particular subject was not associated with teacher effectiveness.

Studies conducted locally by Samuel (1995), Diana Hwang and Mohammad Amin Embi (2007) have focused exclusively on the approaches used by English language teachers to teach the literature component. Others like Fauziah Ahmad and Ura Pin, (2007), Wan Kamariah Baba (2008), Ashairi Sulaiman and Melor Mohd Yunus, 2014), and Fathen Suriati Jusuh (2015) have confined their research to English language teachers and the influence of presage variables. A review of the local records (Educational Planning and Research Division, Ministry of Education and local universities) shows there is still a lack of empirical research on the effects of academic qualifications on the subject matter knowledge of literary devices among English language teachers involved in teaching the Literature Component. Therefore, there exists a gap in the research on the subject matter knowledge of literary devices among English language teachers and the difficulty in using research evidence from abroad, provides the main impetus and thrust of this research.

Given the conspicuous importance in the implementation and teaching of literature in English in the Malaysian secondary schools, there is a need to expedite research on the subject matter knowledge of literary devices. Research findings from abroad are not generalizable to local situations as Boekaerts (1998:87) reminds that "method and practices are by definition culture bound and should be transplanted only with great caution". Hence, there is now a compelling need for local research to be conducted to show whether there are differences or relationships between academic qualifications and subject matter knowledge of literary devices among the four groups of English language teachers.

\section{Literature Review}

The Literature Component in the English language paper at secondary school level was introduced in accordance with the universal changes in the teaching of literature. It is more than a decade since the component was introduced as a tested section of the English language papers in two major public examinations, Pentaksiran Tingkatan Tiga (PT3, Ninth Grade) and Sijil Pelajaran Malaysian (SPM, Eleventh Grade) in Malaysian secondary schools.

The language objective of the Literature Component explicitly mentions of the relationship between literature and language and how literature is a useful resource for learning the English language (Lazar, 1993; Langer, 1997). The Literature Component combines the conventional paradigms of literature which are language, resource and content (Carter and Long, 1991; Leech and Short, 1981). This renewed attempt makes the Literature Component different from the previous programmes like the English Language Reading Programme and Class Reader Programme that included literary texts in the ESL context.

The study of literature using authentic materials is fundamentally a study of the language as both are inseparable and "they create sharp awareness of the communicative potential of the language they are learning" (Widdowson, 1975:81). Coolie and Slater (1987) state literature provides situations where learners are exposed to the diverse uses of grammar and vocabulary. The research by Mahmud Husein Salih (1989) shows that literature helps ESL/EFL learners to acquire native-like competence in English 


\section{EFFECTS OF ACADEMIC QUALIFICATIONS ON MALAYSIAN ENGLISH LANGUAGE TEACHERS' SUBJECT MATTER KNOWLEDGE OF LITERARY DEVICES}

and enhances their knowledge and understanding of linguistics especially literary devices and stylistics. Erkaya (2005) reiterates by integrating literature into language lessons, teachers can help learners to improve the four basic skills and develop higher-order of thinking. Therefore, literary texts have been recommended in language classes as they complement authentic materials that provide genuine language structures (Ibsen, 1990; Hill, 1986). Further, second language learners become aware of the subtle elements that go into the creation of good writing (Gwin, 1990). When literature is incorporated into language lessons, a new dimension is added because it challenges learners linguistically, intellectually, and emotionally as it involves different genres (Spack, 1985; Sage 1987).

Throughout the 1980s there was a shift from prescriptive to descriptive research in teacher education (Grossman, 1991). It stressed on subject matter knowledge that emerged as a new research domain and led to the development of new frameworks on teacher knowledge. These new frameworks were divided into two groups. They were the various categories of teacher knowledge and the growth of teacher knowledge in a combined context, that included "what is teacher's knowledge, how they develop that knowledge and for what it is used in relation to the classroom context" (Grossman, 1991:189).

Researchers have looked at teacher knowledge from diverse perspectives and new terms have emerged to provide an overview of its different aspects. The commonly used terms are "the wisdom of practice" (Schwab, 1971), "action orientated knowledge" (Carter, 1990), "content-related knowledge" (Shulman, 1986), "personal knowledge" (Connelly \& Clandinin, 1985; Elbaz, 1991), "tacit knowledge" (Eraut, 1994; Claderhead \& Robson, 1991), "knowledge based on experience and reflection" (Grimmett \& Mackinnon, 1992; Gunstone, 1999), "content and context related knowledge" (Cochran, DeReite \& King, 1993; Van Driel, Verloop \& De Vos, 1998) and "professional craft knowledge" (Brown \& McIntyre, 1993; Shinmahara, 1998). In this research "subject matter knowledge" consists of all knowledge that underlies teachers' thoughts, practices and actions within the classroom.

Shulman (1987) mentioned subject matter knowledge as the "missing paradigm" in teacher research and expressed teachers needed to know about the subject they taught and reiterated that it was an important factor in teacher development. Others like Darling-Hammond (2000) and the National Commission for Mathematics and Science Teaching for $21^{\text {st }}$ Century (2000) had confirmed that the importance of "well-qualified" or those who majored in the subject they taught, were certified to teach and had greater impact on learners. However, there was tacit agreement among educators that "teachers must know in detail...the content they are responsible for teaching" and general knowledge about the subject was also considered essential (National Mathematics and Science Advisory Panel, 2008:37).

Qualitative research on subject-specific knowledge of teachers revealed that high-quality instructions depended on specific knowledge acquired at university level and did not depend on general knowledge that was obtained casually (Grossman, 2008). Commenting on the same idea, Ojose (2012:151) mentioned that "common sense dictates that we cannot teach what we do not know: content knowledge is needed." He further reiterated that one cannot effectively teach content if they had a superficial and vague understanding of the subject (ibid.). Other researchers had also confirmed that subject specific knowledge of teachers was a decisive factor, which determined the achievement of learners (Hill, Rowan \& Ball, 2005; Baumert et al., 2010; Sadler et al., 2013).

In the postmodern period, the concept of teacher knowledge has been redefined, indicating a shift in the assumptions of knowledge and the relationship between the known and the knower. In teaching, this dichotomy is indicated in the difference between the "product" and "process" approaches. The "product" approach assumes that understanding is part of the knowledge gained and the teacher's role is to guide learners towards self-discovery while the "process" approach assumes him to be a 


\section{EFFECTS OF ACADEMIC QUALIFICATIONS ON MALAYSIAN ENGLISH LANGUAGE TEACHERS' SUBJECT MATTER KNOWLEDGE OF LITERARY DEVICES}

transmitter of knowledge to learners that has been acquired and the "understanding of subject matter is a sine qua non in teaching" (Feiman-Nemser \& Parker, 1990:50). Hashweh (1987) points out teachers with inadequate subject matter knowledge and understanding may be unable to evaluate critically the substance and authenticity of a given text. It has also been revealed that subject matter knowledge included substantive and syntactic knowledge. Anderson and Clark (2012) have defined substantive knowledge as understanding of the body of knowledge generated by the discipline while syntactic knowledge is epistemic knowledge and is related to understanding how ideas are generated and become established norms of a discipline.

\section{Purpose of the Study}

This research paper intends to determine two objectives. The first objective is to determine whether there are differences in the subject matter knowledge of literary devices between English major and non-English major, KPLI (Post-graduate Teaching Programme) and non-KPLI and TESL and nonTESL language teachers. The second objective is to investigate whether there are differences in the subject matter knowledge of literary devices among English major, English minor, KPLI and TESL language teachers. The research questions proposed for this study are as follows:

\section{Methodology}

\section{Research Design}

The issues in this study were addressed by using a quantitative method based on a questionnaire as the primary instrument of data collection.

\section{Location of the Study}

This study was conducted among secondary school English language teachers in a district named Kulim in the state of Kedah which is located in the north of Malaysia.

\section{The Sample}

The targeted sample consisted of 251 English language teachers who taught the English language (Forms One to Five). The sampling procedure considered factors which included the geographical location of the schools and the academic qualifications of English language teachers. The teachers involved in this study were the English major, English minor, TESL and KPLI language teachers. The respondents who were English language teachers in secondary schools had diverse academic qualifications and were chosen as they had been teaching the literature component since its introduction in 2000. The number of teachers in each group was based on information obtained from the local District Education Office. Table 1 show the number of English language teachers in each group.

Table 1: Number of English Language Teachers in Each Group

\begin{tabular}{lc}
\hline Academic Qualifications & $\mathrm{n}$ \\
\hline English major & 39 \\
English minor & 41 \\
TESL & 93 \\
KPLI & 78 \\
\hline Total & 251 \\
\hline
\end{tabular}




\section{EFFECTS OF ACADEMIC QUALIFICATIONS ON MALAYSIAN ENGLISH LANGUAGE TEACHERS' SUBJECT MATTER KNOWLEDGE OF LITERARY DEVICES}

\section{Sampling Procedure}

Permission was obtained from the Educational, Planning and Research Division (EPRD) of the Ministry of Education and the State Education Department (SED) to conduct this research. Subsequently, a district was randomly chosen from the eleven districts in one of the states of Malaysia. The method of random selection was based on the specifications of Gay, Mills and Airasian (2009). After identifying the district, permission was sought from that particular District Education Department (DED) to conduct the study. The 251 English language teachers from this chosen district formed the sample of this study.

Based on the recommendations from the DED, the 26 secondary schools in the district were divided into three clusters namely urban, semi-urban and rural based on the geographical location of these schools. This was to ensure approximately equal representation of academically qualified English Language teachers in each cluster (Gay, Mills \& Airasian, 2009). This form of cluster sampling was used by Tajalarapin Salaiman et al. (2009) and Ikechukwu et al. (2010) in which each school belong to one of the clusters in the specific area or district and all the teachers in that cluster formed an intact group (ibid.). In this research cluster sampling with intact groups was used to ensure all the English language teachers in the district were involved as their number was small. A large sample was essential for inferential statistics.

After selecting the sample, permission was sought from the various school principals to meet the English language teachers. The researcher met all English language teachers from each school after school hours, explained the purpose of this study, then distributed the questionnaires and collected them immediately upon completion. This arrangement was not to disrupt the normal teaching procedure in schools.

\section{Research Instrument}

The research instrument for the study is based on the variables shown in Figure 1.

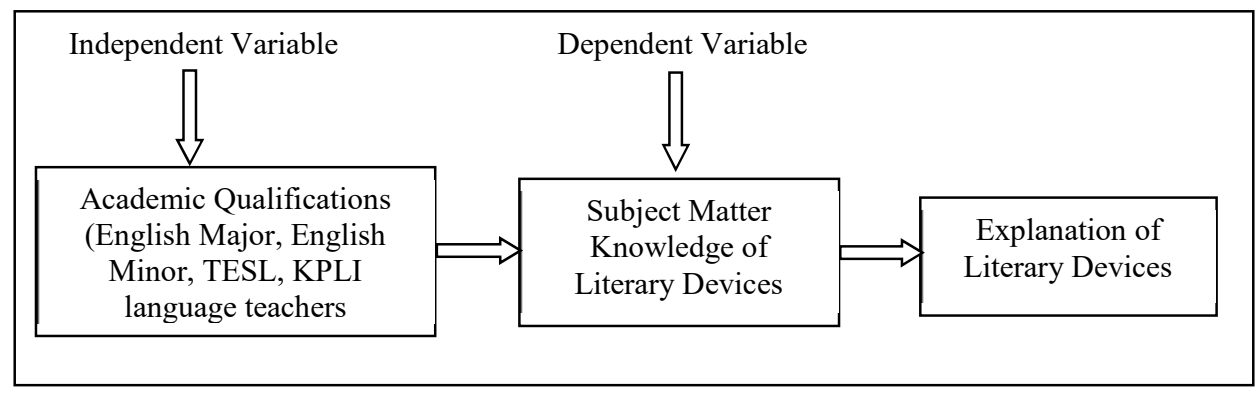

Figure 1: Variables influencing Literary Devices of English Language Teachers, adapted from McCrindle \& Christensen (1995:168)

Figure 1 depicts the variables that influence the explanation of literary texts among English language teachers. The independent variable (academic qualifications) interacts with the dependent variable (subject matter knowledge of literary devices) to influence the explanation of literary texts. Relevant 


\section{EFFECTS OF ACADEMIC QUALIFICATIONS ON MALAYSIAN ENGLISH LANGUAGE TEACHERS' SUBJECT MATTER KNOWLEDGE OF LITERARY DEVICES}

statistical tests were conducted on the data collected to obtain an in-depth understanding of the interaction between academic qualifications and subject matter knowledge of literary devices.

To prepare the questionnaire on literary devices, the following studies were referred to: Widdowson, (1992; 1996), Simpson (1992), Short (1996), Weber (1996), Manan (2000), Verdonk (2002) and Clark and Zyngier (2003). Other local research on literature by Rosli Talif, (1995), Subramanian (2003), Fauziah Ahmad (2007), and Che Tom Mahmud, (2005), and Wan Kamariah Baba (2008) were also used. Research on subject matter knowledge by Ball (1990), Nowlin (1991), Simon (1993), Chalarkid (1994) and Tirosh (2000) were used in the preparation of the questionnaire. The Job analysis questionnaire on knowledge for English Teachers (Wesley, 1993), Designing and Constructing Instruments for Social Research and Evaluation (Colton \& Covert (2007) and The Curriculum specifications for the literature component in the English language curriculum for secondary schools (Ministry of Education, 1999) were used as guidelines.

\section{Data Collection Procedure}

The questionnaire contained two sections. Section A consisted of the demographic profile and Section B contained items related to the subject matter knowledge of literary devices. Subsequently, the questionnaires were validated by two English language experts to determine the clarity and content relevance of the items. The language experts found Section A pertaining to the demographic profile suitable and relevant. They suggested changes to Section B that contained the items related to subject matter knowledge of literary devices. After the necessary amendments had been made, the questionnaire was pilot tested in a different district to establish the reliability and to reduce elements of bias.

As suggested by Hertzorg (2008), $10 \%$ of the total population was involved in the pilot study. Out of the 251 English language teachers, 25 of them participated in the pilot test. The reliability index of the items in Section (B) was 0.781 indicating they were reliable and had measured the variable accurately. The entire questionnaire took about 30 minutes to complete by the respondents. The discussion with the English language teachers did not reveal any major flaw in the questionnaire.

\section{Analysis and Results}

The questionnaire was divided into two sections. Section A provided the demographic information and Section B gathered information on subject matter knowledge of literary devices. Data collected from Section A was analysed for frequency and percentages and Section B was analysed using SPSS version 21 for descriptive and inferential statistics.

The targeted sample was 251 English language teachers and the achieved sample size was 246 giving a return rate of $98 \%$. From Section A of the questionnaire, out of the 246 respondents, $62(24.7 \%)$ of the English language teachers were in the urban, $113(45 \%)$ in the semi-urban and $71(28.3 \%)$ in the rural areas. Female English language teachers constituted $170(67.7 \%)$ while $76(30.3 \%)$ were male. Ethnically, there were 123 (49\%) Malays, 53 (21.1\%) Chinese, and 69 (27.9\%) Indian English language teachers. There were 38 (15.1\%) English major, 40 (15.9\%) English minor, 92 (36.7\%) TESL and 76 $(30.3 \%)$ KPLI English language teachers.

There were 103 (41\%) who had taken literature at Form 5 level, while $143(56.9 \%)$ had not. Professionally, all were trained English language teachers. The analysis revealed 119 (47.8\%) were exposed to literary devices while $125(49.2 \%)$ were not in their undergraduate courses. A large number 


\section{EFFECTS OF ACADEMIC QUALIFICATIONS ON MALAYSIAN ENGLISH LANGUAGE TEACHERS' SUBJECT MATTER KNOWLEDGE OF LITERARY DEVICES}

$217(86.5 \%)$ had attended courses in the teaching of the literature component while $29(11.5 \%)$ had not.

The survey showed $156(62.1 \%)$ agreed subject matter knowledge of literary devices provided insights into the language of the literary texts, $79(31.5 \%)$ disagreed and $11(4.4 \%)$ were uncertain. However, a total of $164(65.3 \%)$ of the English language teachers consented they needed knowledge of literary devices to explore literary texts better while 65 (25.9\%) disagreed and $16(6.4 \%)$ were unsure. Further, $155(61.8 \%)$ agreed understanding of the functions and familiarity with the use of literary devices can influence in explaining literary texts, 60 (23.9\%) disagreed and $30(12 \%)$ were undecided.

Descriptive statistics was used to summarize the items in Section (B) of the questionnaire. The 5-point Likert scale provided the frequency, percentage, mean and standard deviation that were used to interpret the level of mean scores. The researcher used the aggregate mean scores to interpret the different levels of agreement of the items related to the subject matter knowledge of literary devices of English language teachers. The summary of the frequencies, percentages, aggregate mean scores, standard deviations and levels of interpretations of twenty items is shown in Table 2 . The different levels of interpretations are shown in Table 3

Table 2: Summary Showing Frequency, Percentage and Aggregate Mean Scores of English Language Teachers' Subject Matter Knowledge of Literary Devices

\begin{tabular}{|c|c|c|c|c|c|c|c|c|}
\hline \multirow{2}{*}{$\begin{array}{l}\text { Variable } \\
\text { Subject Matter } \\
\text { Knowledge of } \\
\text { of Literary } \\
\text { Devices }\end{array}$} & \multicolumn{5}{|c|}{ Frequency and Percentage } & \multirow{2}{*}{$\begin{array}{l}\text { Aggregate } \\
\text { Mean } \\
\text { Scores }\end{array}$} & \multirow{2}{*}{$\begin{array}{c}\text { Standard } \\
\text { Deviation }\end{array}$} & \multirow{2}{*}{$\begin{array}{l}\text { Level } \\
\text { Interpretation }\end{array}$} \\
\hline & $\begin{array}{l}\text { Strongly } \\
\text { Disagree }\end{array}$ & Disagree & $\begin{array}{l}\text { Moderate } \\
\text { Agree }\end{array}$ & Agree & $\begin{array}{l}\text { Strongly } \\
\text { Agree }\end{array}$ & & & \\
\hline 1. provides & & & & & & & & \\
\hline $\begin{array}{l}\text { linguistic } \\
\text { analysis of } \\
\text { literary texts }\end{array}$ & $\begin{array}{c}1 \\
0.4 \%\end{array}$ & $\begin{array}{c}1 \\
0.4 \%\end{array}$ & $\begin{array}{c}76 \\
30.9 \%\end{array}$ & $\begin{array}{c}128 \\
52.0 \%\end{array}$ & $\begin{array}{c}40 \\
16.3 \%\end{array}$ & 4.31 & 0.48 & $\begin{array}{c}\text { Strongly } \\
\text { Agree }\end{array}$ \\
\hline $\begin{array}{l}\text { 3. does not } \\
\text { discriminate the } \\
\text { types of texts } \\
\text { chosen for study }\end{array}$ & 0.0 & $\begin{array}{c}14 \\
5.7 \%\end{array}$ & $\begin{array}{c}73 \\
29.7 \%\end{array}$ & $\begin{array}{r}118 \\
48.0 \%\end{array}$ & $\begin{array}{c}41 \\
16.7 \%\end{array}$ & 4.23 & 0.59 & $\begin{array}{c}\text { Strongly } \\
\text { Agree }\end{array}$ \\
\hline $\begin{array}{l}\text { 10. helps to } \\
\text { understand } \\
\text { linguistic } \\
\text { features of } \\
\text { literary texts } \\
\text { and relate them } \\
\text { to the literary } \\
\text { features to } \\
\text { show meanings }\end{array}$ & $\begin{array}{l}1 \\
0.4 \%\end{array}$ & $\begin{array}{c}7 \\
2.8 \%\end{array}$ & $\begin{array}{c}60 \\
24.3 \%\end{array}$ & $\begin{array}{r}134 \\
54.3 \%\end{array}$ & $\begin{array}{r}45 \\
18.2 \%\end{array}$ & 4.26 & 0.55 & $\begin{array}{c}\text { Strongly } \\
\text { Agree }\end{array}$ \\
\hline
\end{tabular}




\section{EFFECTS OF ACADEMIC QUALIFICATIONS ON MALAYSIAN ENGLISH LANGUAGE TEACHERS' SUBJECT MATTER KNOWLEDGE OF LITERARY DEVICES}

2. analyses

literary texts

from language, intermediate

and

$\begin{array}{cc}9 & 89 \\ 3.7 \% & 36.2 \%\end{array}$

135

13

3.62

0.65

Agree

communication

54.9

$5.3 \%$

levels

4. has widened

language use to understand

context,

meaning and

$\begin{array}{cccc} & 7 & 72 & 144 \\ 0.0 & 2.8 \% & 29.3 \% & 58.5 \%\end{array}$

23

3.74

0.66

Agree

communication

al implications

of literary

texts.

5. uses language to analyse literary

texts making it

suitable for non-

native learners of

English.

$\begin{array}{llr}1 & 2 & 85\end{array}$

122

37

3.78

0.72

Agree

6. provides

linguistic insight

into literary texts

without

$\begin{array}{ccc} & 8 & 78 \\ 0.0 & 3.3 \% & 32.0 \%\end{array}$

133

25

3.72

0.68

Agree

compromising o

aesthetic

qualities

7. provides

language

awareness to

read between

lines and

0.

$\begin{array}{cc}13 & 78 \\ 5.7 \% & 31.6 \%\end{array}$

124

31

3.82

$12.6 \%$

meaning of

literary texts.

8. insufficient as

background

knowledge is

required to

understand

literary texts.

$0.0 \quad 2.4 \%$

51

160

30

3.82

0.64

Agree

9. provides a

linguistic

medium that

helps to relate

0.0

13

83

$5.3 \% \quad 33.6 . \%$

119

32

3.69

0.73

Agree

personal $13.0 \%$

experiences 


\section{EFFECTS OF ACADEMIC QUALIFICATIONS ON MALAYSIAN ENGLISH LANGUAGE TEACHERS' SUBJECT MATTER KNOWLEDGE OF LITERARY DEVICES}

11. helps in

understanding different variations of language use in 0.0 11

110

119

6

3.49

0.6

literary texts

$4.5 \%$

$44.7 \%$

$48.4 \%$

$2.4 \%$

12. prepares for other forms like literary criticism

$\begin{array}{cccc}1 & 16 & 126 & 98 \\ & 6.6 \% & 52.5 \% & 40.5 \%\end{array}$

0.0

3.33

0.62

Agree

15. helps to develop confidence to understand writer's language

2

114
$46.5 \%$

$\begin{array}{cc}107 & 1 \\ 43.7 \% & 0.4 \%\end{array}$

3.60

$0 \quad 64$

Agree

17. provides linguistic medium that helps to relate literary texts to personal experience.

$\begin{array}{cc}3 & 20 \\ 1.2 \% & 8.2 \%\end{array}$

147 $60.0 \%$ 70

5

13. enables to understand linguistic associations in literary texts reveal the styles of language. $28.6 \% \quad 2.0 \%$

14. knowledge of stylistics helps to teach all forms of $\begin{array}{ccc}1 & 25 & 116 \\ 0.4 \% & 10.3 \% & 47.7 \%\end{array}$ 100 1 3.10 0.64 $41.2 \%$ literary texts.

16. relates the linguistic features to the literary aspects besides describing them to bring out meanings.

18. helps to understand literary texts as 


\section{EFFECTS OF ACADEMIC QUALIFICATIONS ON MALAYSIAN ENGLISH LANGUAGE TEACHERS' SUBJECT MATTER KNOWLEDGE OF LITERARY DEVICES}

a linguistic entity and is different from the traditional practical criticism

$\begin{array}{ccccccc}0 . .0 & 19 & 136 & 87 & 2 & 3.10 & 0.69 \\ & 7.6 \% & 55.7 \% & 35.7 \% & & & \end{array}$

69

Moderately Agree

19. increases awareness of the conventions that govern language of writers.

20. provides a linguistic framework to understand the language in literary texts.

$\begin{array}{ccc}0.0 & 18 & 129 \\ & 7.4 \% & 52.9 \%\end{array}$

93

$38.1 \%$
67

$0.0 \quad 15.5 \%$

139

$27.3 \%$

1

$0.4 \%$

3.30

0.63

Moderately

Agree

From the analysis of the twenty items on the subject matter knowledge of literary devices, items 1, 3, 10 belong to the strongly agree group. Eleven other items namely 2, 4, 5, 6, 7, 8, 9, 11, 12, 15, 17 were in the agree category. The remaining six items $(13,14,16,18,19,20)$ were classified under the moderately agree group.

The different levels of demarcation of the aggregate mean scores were done according to Table 3 . There were five categories ranging from strongly disagree to strongly agree.

Table 3 Interpretation of Aggregate Mean Scores

\begin{tabular}{lc}
\hline Categories & Aggregate Mean Scores \\
\hline Strongly Disagree & $1.00--------1.80$ \\
Disagree & $1.81---------2.60$ \\
Moderate Agree & $2.61--------3.40$ \\
Agree & $3.41-------4.20$ \\
Strongly Agree & $4.21-------5.00$ \\
\hline
\end{tabular}

Source: score category adopted from Fauziah Ahmad (2003)

Prior to the statistical analysis the data was tested for normality. The results of the KolmogorovSmirnov test conducted to establish the normality of the data is depicted in Table 4. This test based on the Lilliefor's significance level had a small K-S statistic that was not significant and the $p$ value was greater than 0.05 , therefore normality was assumed and values of the items were normally distributed.

Table 4 Kolmogorov- Smirnov test for normality 


\section{EFFECTS OF ACADEMIC QUALIFICATIONS ON MALAYSIAN ENGLISH LANGUAGE TEACHERS' SUBJECT MATTER KNOWLEDGE OF LITERARY DEVICES}

\begin{tabular}{lccc}
\hline & \multicolumn{3}{c}{ Kolmogorov-Smirnov $^{\mathrm{a}}$} \\
& Statistic & $d f$ & Sig. \\
\hline $\begin{array}{l}\text { Number of items in } \\
\text { questionnaire 20 }\end{array}$ & .055 & 247 & .064 \\
\hline
\end{tabular}

a. Lilliefors Significance Correction for Normality

This study examines the

differences in the subject matter knowledge of literary devices among the four groups of English language teachers. To determine these differences, measures of variability and independent group $t$ tests were conducted on three groups namely English major and non-English major, TESL and nonTESL and KPLI and non- KPLI English language teachers. Further analysis of variance (ANOVA) was conducted to establish if differences existed among the four groups namely English major, English minor, TESL and KPLI language teachers.

Comparison between English major and non-English major language teachers in their subject matter knowledge of literary devices

The questionnaires were analysed statistically by using the Independent sample $t$-test to determine whether there were differences in the subject matter knowledge of literary devices between the English major and non-English language teachers. The analyses of the results are depicted in Table 5.

Table 5: Descriptive Statistics and Independent $t$-Test Comparison for Subject Matter Knowledge of Literary Devices between English Major and Non-English Major Teachers

\begin{tabular}{|c|c|c|c|c|c|c|c|}
\hline Groups & $N$ & $M$ & $S D$ & $d f$ & $T$ & $p$ & $d$ \\
\hline English major & 32 & 3.20 & 0.27 & & & & \\
\hline $\begin{array}{r}\text { Non-English } \\
\text { minor }\end{array}$ & 214 & 3.00 & 0.40 & 244 & 2.88 & $0.004^{*}$ & 0.49 \\
\hline
\end{tabular}

The mean for the English major language teachers was 3.20 and the standard deviation was 0.27 and the mean for the non-English major language teachers was 3.00 and the standard deviation was 0.40 respectively. The Levene's test of equality of variance showed $F=(5.23), p>0.05$, that indicated no violation of the assumption of homogeneity of variance between the groups of English language teachers. Therefore, the equal variance assumption statistics was reported. The results of the Independent sample $t$-test revealed there was a significant difference in the subject matter knowledge of literary devices between the English major and non-English major language teachers, $t(d f=244)$ $=2.88 ; p=0.004$. Based on the mean the English major language teachers had higher subject matter knowledge of literary devices than the non-English major language teachers. The computed Cohen's $d=0.49$ which was in the range of small effect size indicated the difference in the subject matter knowledge of literary devices was small but discernable.

Comparison between KPLI and non-KPLI English language teachers in their subject matter knowledge of literary devices

In order to establish whether there were differences in the subject matter knowledge of literary devices between the KPLI and non-KPLI English language teachers, the questionnaires were analysed. The results are reported in Table 6. 


\section{EFFECTS OF ACADEMIC QUALIFICATIONS ON MALAYSIAN ENGLISH LANGUAGE TEACHERS' SUBJECT MATTER KNOWLEDGE OF LITERARY DEVICES}

Table 6: Descriptive Statistics and Independent $t$ - Test Comparison for Subject Matter Knowledge of Literary Devices between KPLI and Non-KPLI Language Teachers

\begin{tabular}{|c|c|c|c|c|c|c|c|}
\hline Groups & $n$ & $M$ & $S D$ & $d f$ & $T$ & $p$ & $d$ \\
\hline KPLI & 76 & 2.97 & 0.43 & 244 & 2.91 & $0.002^{*}$ & 0.45 \\
\hline $\begin{array}{l}\text { Non- } \\
\text { KPLI }\end{array}$ & 170 & 3.10 & 0.30 & & & & \\
\hline
\end{tabular}

The analysis revealed the mean for the KPLI English language teachers was $2.97(S D=0.43)$ and the mean for the non-KPLI was $3.10(S D=0.30)$ respectively. The Levene's test indicated there was no violation of the assumptions of homogeneity of variance, $F=5.56, p>0.05$. Based on this result the equal variance statistics was reported. The results from the Independent sample $t$-test revealed there was a significant difference in the subject matter knowledge of literary devices between the KPLI and non-KPLI English language teachers, $t(d f=244)=2.91, p=0.002$. The higher mean for the non-KPLI English language teachers indicated they had better subject matter knowledge of literary devices than KPLI. The Cohen's $d$ was 0.45 which was in the range of small effect size indicated the difference in the subject matter knowledge of literary devices between the two groups small.

Comparison between TESL and non-TESL English language teachers in their subject matter knowledge of literary devices

The results of the analysis of the questionnaires are reported in Table 7.

Table 7: Descriptive Statistics and Independent $t$-Test Comparison for Subject Matter Knowledge o Literary Devices between TESL and Non-TESL Teachers

\begin{tabular}{cccccccc}
\hline Groups & $n$ & $M$ & $S D$ & $d f$ & $T$ & $p$ & $d$ \\
\hline TESL & 92 & 3.11 & 0.35 & & & & \\
& & & & 244 & 2.76 & & 0.48 \\
Non- & 154 & 3.00 & 0.26 & & & & \\
TESL & & & & & & & \\
\hline${ }^{\mathrm{p}<0.05}$ & & & & & & &
\end{tabular}

The mean for the TESL teachers was 3.11 and the standard deviation was 0.35 while the mean for the non-TESL teachers was 3.00 and the standard deviation was 0.26 respectively. The analysis of the Levene's test revealed there was no violation of the assumptions of homogeneity of variance, $F=5.66$, $p>0.05$. The equal variance assumed $t$ statistics was quoted. The Independent $t$-test indicated there was a significant difference in the subject matter knowledge of literary devices between the TESL and non-TESL language teachers, $t(d f=244)=. t=2.76, p=0.48$. As indicated by the mean, the TESL English language teachers had higher subject matter knowledge of literary devices than the non-TESL English language teachers. The Cohen's $d=0.48$ was in the range of small effect size that suggested the difference in the subject matter knowledge of literary devices between the two groups was small. 


\section{EFFECTS OF ACADEMIC QUALIFICATIONS ON MALAYSIAN ENGLISH LANGUAGE TEACHERS' SUBJECT MATTER KNOWLEDGE OF LITERARY DEVICES}

Comparison to show differences in the subject matter knowledge of literary devices among four groups of English language teachers

Table 8 shows the descriptive statistics of the four groups of English language teachers namely, English major, English minor, KPLI and TESL and also the means and standard deviations of the four groups.

Table 8: Descriptive Statistics of English Language Teachers

\begin{tabular}{ccccc}
\hline Groups of English language teachers & $n$ & Percentage & Mean & $S D$ \\
\hline English major & 32 & 13.0 & 3.20 & 0.27 \\
English minor & 46 & 18.7 & 3.15 & 0.31 \\
TESL & 92 & 37.4 & 3.11 & 0.35 \\
KPLI & 76 & 30.9 & 2.94 & 0.43 \\
Total & 246 & 100 & 3.53 & 0.52 \\
\hline
\end{tabular}

The mean for the English major language teachers was $3.20(S D=0.27)$, the mean for the English minor language teachers was $3.15(S D=0.31)$, the mean for the TESL English language teachers was 3.11 $(S D=0.35)$ and the mean for the KPLI language teacher was $2.94(S D=0.43)$.

The Levene's test based on the descriptive statistics indicated unequal variance among the four groups of English language teachers in their subject matter knowledge of literary devices, $F(3,242)=2.39$, $p>0.05$. The one-way ANOVA was conducted to determine explicitly if there were significant differences in the subject matter knowledge of literary devices among the four groups of English language teachers. The results are reported in Table 9.

Table 9: One-Way ANOVA Comparison for Subject Matter Knowledge of Literary Devices among Four Groups of English Language Teachers

\begin{tabular}{lcccccc}
\hline $\begin{array}{l}\text { Subject Matter } \\
\text { Knowledge of } \\
\text { Literary devices }\end{array}$ & $\begin{array}{c}\text { Sum of } \\
\text { Squares }\end{array}$ & Df & $\begin{array}{c}\text { Mean } \\
\text { Square }\end{array}$ & $F$ & Sig & $\eta^{2}$ \\
\hline Between Groups & 7.47 & 3 & 2.49 & 5.38 & $0.001^{*}$ & 0.05 \\
Within Groups & 111.7 & 242 & .461 & & & \\
Total & 119.17 & 245 & & & & \\
\hline \multicolumn{7}{l}{ The mean difference is significant at the 0.05 level }
\end{tabular}

The analysis of the one-way ANOVA revealed there was a significant difference among the four groups of English language teachers $F(3,242)=5.38, p=0.001$. The partial eta squared $\left(\eta_{\mathrm{p}}{ }^{2}\right)$ generated $=0.05$ showed the effect size was small and the difference in the subject matter knowledge of literary devices were discernable.

Scheffe post hoc multiple comparison test was conducted as appropriate to determine explicitly which groups were significantly different. The results are presented in Table 10.

Table 10:Scheffe Multiple Comparison Test for Subject Matter Knowledge of Literary among the Four Groups of English Language Teachers 
EFFECTS OF ACADEMIC QUALIFICATIONS ON MALAYSIAN ENGLISH LANGUAGE TEACHERS' SUBJECT MATTER KNOWLEDGE OF LITERARY DEVICES

\begin{tabular}{clllc}
\hline $\begin{array}{c}\text { Academic } \\
\text { Qualification } \\
\text { (I) }\end{array}$ & $\begin{array}{c}\text { Academic } \\
\text { Qualifications } \\
(\mathrm{J})\end{array}$ & $\begin{array}{c}\text { Mean } \\
\text { Difference } \\
(I-J)\end{array}$ & Std. Error & Sig. \\
\hline English major & English minor & 0.05 & .09 & $0.028^{*}$ \\
& TESL & 0.09 & .09 & $0.004^{*}$ \\
& KPLI & 0.26 & .09 & $0.001^{*}$ \\
English Minor & English major & -0.05 & .09 & $0.028^{*}$ \\
& TESL & 0.04 & .09 & 0.906 \\
TESL & KPLI & 0.21 & .09 & 0.807 \\
& English Major & -0.09 & .09 & $0.004^{*}$ \\
KPLI & English Minor & -0.04 & .09 & 0.906 \\
& KPLI & 0.17 & .09 & 0.503 \\
& English Major & -0.26 & .09 & $0.001^{*}$ \\
& English Minor & -0.21 & .09 & 0.807 \\
& TESL & -0.17 & .08 & 0.503 \\
\hline
\end{tabular}

From the Scheffe post hoc multiple comparison test, it was found the English major language teachers were significantly different in their subject matter knowledge of literary devices from the English minor (mean difference $=0.05, p=0.028$ ), TESL (mean difference $=0.09, p=0.004$ ) and KPLI (mean difference $=0.26, p=0.001$ ) language teachers.

The Scheffe post hoc multiple comparison test also revealed English minor language teachers were not significantly different in their subject matter knowledge of literary devices from the TESL (mean difference $=0.04, p=0.906$ ), and KPLI (mean difference $=0.21, p=0.807$ ) language teachers.

The analysis based on the Scheffe post hoc multiple comparison test revealed the TESL language teachers were not significantly different in their subject matter knowledge of literary devices from the KPLI (mean difference $=0.17, p=0.503$ ).

\section{Discussion and Conclusion}

The study explicitly indicates there are differences in the subject matter knowledge of literary devices among English language teachers based on their academic qualifications.

The English major language teachers who were numerically smaller (13\%) than the non-English majors $(87 \%)$ language teachers had revealed a higher level of subject matter knowledge of literary devices. Their academic courses were completely a combination of literature and language that provided the conceptual depth, and had enriched their subject matter knowledge of literary devices. The non-English major language teachers consisted of a combination of three groups namely English minor, KPLI and TESL language teachers. These three groups had undergone fewer English literature and language courses in their undergraduate programme that could have contributed to their knowledge of literature and had influenced their subject matter knowledge of literary devices. The results corroborate with the findings of Martin et al. (2000) and Wenglinsky (2000) who found that those who had majored in specific subjects were better and more effective in their subject matter knowledge than non-major language teachers.

The TESL language teachers (37.4\%) had higher level of subject matter knowledge of literary devices than their non-TESL counterparts $(62.6 \%)$. The academic courses of the TESL teachers contained the literature component as a 'minor' subject in their language programme (Khan, 2003). This component had enabled them to acquire sufficient literary knowledge and understanding of literary devices that 


\section{EFFECTS OF ACADEMIC QUALIFICATIONS ON MALAYSIAN ENGLISH LANGUAGE TEACHERS' SUBJECT MATTER KNOWLEDGE OF LITERARY DEVICES}

helped them to excel. Their high level of subject matter knowledge can be justified by what Kennedy (1991:14) referred to as "majoring in an academic subject in college may not necessarily guarantee that teachers will have the kind of subject matter knowledge they need for teaching". As Little and McLaughlin (1993) and Varella (1997, 2000) had favorably argued that such programmes can uplift teachers' subject matter knowledge and their instructional practices. In the non-TESL group there was only a small percentage like the English major (13\%) language teachers who studied literature per se. while the English minor (18.7\%) had studied fewer literature courses. The KPLI English language teachers $(30.9 \%)$ had majored in other subjects like history, geography or computer science, their training prioritized the pedagogical aspects of teaching the English language and literature in English was only a minor component. The diverse academic qualification between the TESL and non-TESL teachers and the disparity in their literature programmes had revealed their differences in the subject matter knowledge of literary devices.

The KPLI (30.9\%) had lower subject matter knowledge than non-KPLI language teachers. They were 'out-of-field' English language teachers who had undergone courses in the pedagogical aspects of teaching the language. However, the fewer literature courses in their programme provided the essential literary knowledge that enabled them to teach the literature component. Furthermore, the "quick entry" of this group contributed to their limited subject matter knowledge of literature and literary devices when compared to the traditional and 'in-field' group like the English major language teachers (Newton-Newton, 1999). The KPLI with their "alternative quick-entry" qualifications, were less effective in their subject matter knowledge (Wayne and Youngs, 2003) and were unable to compete with teachers of traditional programmes (Grossman, 1989; Darling-Hammond, 1991). The non-KPLI group consisted of English major, minor and TESL teachers who had been academically exposed to more literature and language courses that provided the edge over their KPLI counterparts.

The overall results confirmed the findings of Porter and Borphy (1988) and Wayne and Youngs (2003) who claimed that majoring in a particular subject provided better subject matter knowledge. Based on the analysis, it was evident that those who had majored in as single like English were better than the English minor, TESL and KPLI language teachers. The results supported the evidence provided by Porter and Borphy (1988) and Norrel (1994) who had mentioned that those who had majored in single subjects had strong subject matter knowledge and were better prepared that who had followed the "alternative quick entry" courses like the English minor, TESL and KPLI language teachers. The results of the analysis also refuted the evidence provided by Kennedy (1991), Martin et al. (2000) and Wenglinsky (2000) and who had mentioned that subject majors did not possess the right kind of subject matter knowledge they required to teach effectively.

The analysis also indicated that there was no significant difference in the subject matter knowledge of literary devices among the "out-of-field" teachers like the English minor, TESL and KPLI language teachers. The results confirmed the evidence put forward by Grossman, 1989, Newton-Newton (1999) Darling-Hammond (2000) and Wayne and Youngs (2003) who had indicated that there was little difference among the "out-of-field" teachers compared to the "in-field" teachers like the English majors.

The present findings have revealed two distinct patterns of relations between academic qualifications and subject matter knowledge of literary devices among English language teachers. The first pattern showed the English major, English minor, TESL and KPLI language teachers had manifested significant differences in their subject matter knowledge of literary devices. Their differences can be attributed to the diverse literature courses they had studied that were offered by the various public and private tertiary institutions. The results of the study confirmed the opinions of Darling Hammond 


\section{EFFECTS OF ACADEMIC QUALIFICATIONS ON MALAYSIAN ENGLISH LANGUAGE TEACHERS' SUBJECT MATTER KNOWLEDGE OF LITERARY DEVICES}

(2000, 2002), Goldhaber (2002) and Hattie (2003) who had mentioned that those with subject specific degrees had demonstrated a better grasp of knowledge than others.

The second pattern revealed there was no difference in the subject matter knowledge of literary devices among English minor, KPLI and TESL teachers. They were all non-English major language teachers, who had basic knowledge of literature as they had followed the "alternative quick-entry" courses to teach the literature component. The three groups had no significant differences in their subject matter knowledge of literary devices as they were either majors in other subjects or pedagogically trained to teach the language (Wong, 2003).

The findings of this study provide useful insights regarding the importance of subject matter knowledge of literary devices in teaching the literature component. As it has been revealed by the analysis, there is a strong relationship between subject matter knowledge of literary devices and academic qualifications. The evidence obtained in this research can further enlighten the Ministry of Education generally and specifically the Teacher Education Division (TED) as to what needs to be included when providing assistance to English Language teachers. The TED can design new modules, teaching files and worksheets and a literature web page to compensate for the shortcomings that have been identified in the instructional practices of those who are involved in teaching the Literature Component. Subsequently, new literature programmes using literary devices and stylistics can be developed to ensure a language-based approach in line with the objectives that have been mentioned in the literature component.

The results of the study have indicated there is a disparity in the subject matter knowledge of literary devices among the four groups of English language teachers. Hence, there is a need for remedial measures to be introduced in order to offset the imbalance and reduce the disparity among the four groups. Both short and long term measures can be introduced to address the existing situation. As short term measures TED should conduct in-service courses in the teaching of literature using literary devices. These courses should be conducted by experts in the field of literature so as to upgrade the subject matter knowledge of literary devices, especially among the non-English major language teachers.

As long term measures, public and private institutions of higher learning as well as teacher training institutions should incorporate more courses in literature that contain subject matter knowledge of literary devices. These courses can provide the necessary input that can be helpful when language teachers are required to teach the literature component. These measures can narrow the gap between the English major and non-English major language teachers.

\section{References}

Ashairi Suilaiman \& Melor Md. Yunus. (2014). A Glimpse on the Re-Introduction of English Literature in Malaysian Secondary Schools. International Journal of Languages and Literature. Vol. 2 (2): 151-164.

Ball, D. L. (1990). The mathematical understandings that perspective teachers bring to teacher education. Elementary School Journal, Vol. 90: 449-513.

Baumert, J., Kanuter, M., Blum, W., Brunner, M., Voss, T., Jordan, A., Tsai, Y. (2010). Teacher's mathematical knowledge, cognitive activation in the classroom and student progress. American Educational Research Journal, Vol. 47: 133-180. 


\section{EFFECTS OF ACADEMIC QUALIFICATIONS ON MALAYSIAN ENGLISH LANGUAGE TEACHERS' SUBJECT MATTER KNOWLEDGE OF LITERARY DEVICES}

Boekaerts, M. (1998). Do culturally rooted self-constructs affect students' conceptualization of controls over learning? Educational Psychologist. Vol. 33: 87-108.

Brown, S, \& McIntyre, D. (1993) Making Sense of Teaching. Buckingham, Open University Press.

Carter, K. (1990). Teachers' knowledge and learning to teach. In W. R. Houston, M. Haberman, J. Sikula (Eds.). Handbook of Research on Teacher Education ( $4^{\text {th }}$ ed.). New York. Macmillan: 292-310.

Carter, R. \& Long, M. N. (1991). Teaching Literature. London: Longman Pub.

Chalarkid, P. (1994). Test developments of mathematics subject matter knowledge levels of divisions of rational numbers for Thai pre-service elementary teachers. Unpublished Ph.D Thesis. Oregon State University, USA.

Che Tom Mahmud. (2005). Literature Instruction in Selected Rural Secondary Schools in Perak. Unpublished Ph.D Thesis. University Kebangsaan Malaysia, Malaysia.

Clark, U. \& Zyngier, S. (2003). Towards a pedagogical literary devices. Language and Literature, Vol. 12 (40): 339-35

Cochran, F.K., DeReiter, J. A., \& King, R.A. (1993). Pedagogical content knowing: an integrative model for teacher preparation. Journal of Teacher Education, 44:261-272.

Connelly, F. M., \& Cladinin D. J. (1985). Personal practical knowledge and the ways of knowing. Relevance for teaching and learning. In E. Eisrner (Ed.). Learning and teaching the ways of knowing. Chicago: Chicago University Press, 174-197.

Colton, D., \& Covert, R.W. (2007). Designing and Constructing Instruments for Social Sciences and Evaluation. Jossey Bass: San Francisco, CA.

Coolie, J. \& Slater, L. (1987). Literature in the language classroom. Avon: Cambridge University Press.

Darling-Hammond, L (2000). Teacher quality and student achievement: A review of state policy evidence. Education policy analysis archives. (81).

Diana Hwang \& Mohd. Amin Embi. (2007).Approaches employed by secondary school teachers to teach the literature component in English. Journal Pendidikan. Jil 22: 1-23.

Elbaz, F. (1991). Research on Teacher Knowledge. The evolution of a discourse. Curriculum Studies. Vol. 22(1): 1-19.

Eraut, M. (1994). Developing professional knowledge and competence. London: Falmer Press.

Erkaya, O. K. (2005). Benefits of using short stories in the EFL context. Asian EFL Journal. Vol. 8: 113.

Fauziah Ahmad. (2003). The Incorporation of the Literature Component in the Malaysian ESL Syllabus for Secondary Schools: A Study of Pedagogical Implications. Journal of 3L: Language, Linguistics, Literature. Vol. 14: 49-73. 


\section{EFFECTS OF ACADEMIC QUALIFICATIONS ON MALAYSIAN ENGLISH LANGUAGE TEACHERS' SUBJECT MATTER KNOWLEDGE OF LITERARY DEVICES}

Fauziah Ahmad. (2007). Teachers' Thought process in teaching literature: Good leadership and administration in teaching, Jurnal Pengurusan \& Kepimpinan Pendidikan Kuala Lumpur. Vol. 44 (1): $55-63$

Fauziah Ahmad \& Ura Pin. (2007). Teaching Literature: Influencing Presage Variables. Jurnal Penyelidikan Pendidikan. Kementerian Pelajaran Malaysia,Vol. 9: 63-92.

Fathen Suriati Jusuh. (2015). The Effects of Using pictures and Illustrations in Teaching Literature Novel to Form 3 Struggling and Reluctant Readers. Jurnal Penyelidikan Pendidikan. Vol.16: 100-109.

Feiman-Nemser, S., Parker, M. (1990). Making subject matter part of the conversation in learning to teach. Journal of Teacher Education. 44 (1): 55-63.

Gay, L. R., Mills, G E., \& Airasian, P. (2009). Educational Research. New Jersey. Pearson.

Goldhaber, D. D., and Brewer, D. J. (2000). Does teacher certification matter? High School certification status \& student achievement. Education Evaluation \& Policy Analysis, 22, $122-$ 145.

Goldhaber, D. D., and Brewer, D. J. (1996). Evaluating the effects of teacher degree level on educational performance. Washington D.C.: NCES.

Grimmett, P.P., Mackinon (1992). Craft knowledge and the education of teachers. In G. Brant (Ed.). Review of Research in Education, Vol. 18: 385-456). Washington: AERA.

Grossman, P. L. (1989). Teachers' of Substance: Subject Matter Knowledge in Teaching. In Reynolds, M., C., (Ed.). Knowledge Base for the Beginning Teachers. Pergamon Press. Oxford.

Grossman, P. L. (1991). Mapping the terrain. Knowledge growth in teaching. In H. C. Waxman \& H. J. Walberg (Eds.). Effective Teaching. Current Research. Barkeley. CA: McCuthema: 183-299.

Gunstone, R. (1999). Content knowledge and their intertwining: A response to the paper set. Science Education, 83 (3): 393-396.

Hattie, J. (2003). Teachers make a difference. What is research evidence? Paper presented at Australian Council for Educational Research Conference.

Gwin, T. (1990). Language skills through literature. FORUM XXVIII (3):10-13.

Hashweh, M. Z. (1987). Effects of subject matter knowledge in teaching biology and physics. Teaching and teacher education. International Journal of Research and Studies. Vol. 3: 109-120.

Hill, J. (1986). Teaching of Literature in the language Classroom. London: Macmillan Pub.

Hill, H. C., Rowan, B., \& Ball, D.C., (2005). Effects of teachers, mathematics knowledge for teaching on students' achievement. American Educational Research Journal. 42 (2): 370-406. 


\section{EFFECTS OF ACADEMIC QUALIFICATIONS ON MALAYSIAN ENGLISH LANGUAGE TEACHERS' SUBJECT MATTER KNOWLEDGE OF LITERARY DEVICES}

Ibsen, E. B. (1990). The double role of fiction in foreign language learning. Towards a creative methodology. English Teaching Forum: 2-7.

Ikechukwu Abu, Siti Nor Yaacob, \& Rumaya Juhari. (2010). Bullying and its relationship with depression among Teenagers. Journal of Psychology, 1 (1): 15-22.

Kennedy, M. (1991). Some surprising findings on how teachers learn to teach. Educational Leadership. Vol. 49: 14-17.

Khan, A. K. S. (2003). Pedagogical Implications of the Incorporation of the Literature Component in the Malaysian ESL Syllabus. In Vethamani, M. E. (Ed.). Teaching Literature in ESL/EFL Contexts. Petaling Jaya Selangor, (Malaysia). Sasbadi Pub. 49-6.1

Langer, J. (1997). Literacy Acquisition through Literature. Journal of Adolescent and Adult Study, 40: $602-614$.

Lazar, G. (1993). Literature and language teaching. A Guide for Teachers \& Trainers. Cambridge: Cambridge University Press.

Leech, G. N. \& Short, M. (1981). Style in Fiction: A Linguistic introduction to English Fictional Prose. New York, Longman.

Little, J., \& McLaughlin. M. (Eds.) (1993). Teachers'work: Individuals, colleagues and contents. New York: Teachers College Press.

Mahmud Husien Salih. (1989). From language to literature in the University English Department. Forum, Vol. 27 April: 25-27.

Manan, S. (2000). Developing Critical skills: using stylistics in the ESL literature classroom. MELTA (http://melta.org/modules/sections/4/doc.

Martin, M. O., Mullis, I. V. S., Gregory, K. D. H., Hoyle, C., \& Shen, C. (2000). Effective schools in science and mathematic, Chesnut Hill, M.A. International Study Center, Boston College Press.

McCrindle, A., R., \& Christensen, C. A. (1995). The impact of leaning journals in metacognitive and cognitive processes and learning experiences. Learning and Instruction, 3: 168 -185.

Ministry of Education. (2000). Circular on the teaching of literature component to State Education Departments.

Ministry of Education. (1999). Curriculum specifications for the literature component in the English language curriculum for secondary schools. Kuala Lumpur; 13.

Newton, D. P., \& Newton, L. D. (1999). Knowing what counts as understanding in different disciplines. Educational Studies. Vol. 25: 35-52.

Norrel, M. H. (1994). Sources of critical theory for secondary English teachers. Levels of authority in college literature classrooms. Unpublished Ph.D Thesis, George Mason University, USA. 


\section{EFFECTS OF ACADEMIC QUALIFICATIONS ON MALAYSIAN ENGLISH LANGUAGE TEACHERS' SUBJECT MATTER KNOWLEDGE OF LITERARY DEVICES}

Nowlin, D. (1991). The development and validation of an instrument as access cognitive domain status of pre-service and in-service elementary teachers' in the division of rational numbers. Unpublished Ph.D Thesis, Oregon State University, USA.

Porter, A. C. \& Borphy, J. C. (1988). Synthesis of Research on good teaching. Insight from the work of the institute for research on teaching. Educational Leadership Vol. 45 (8): 74-78.

Rosli Talif. (1995). Teaching of Literature in the ESL: The Malaysian Context. Kuala Lumpur. University Putra Malaysia.

Sadler, P., Sonnert, G., Coyle, H. P., Cook-Smith, N., Miller, J. L. (2013). The influence of teachers' knowledge of student learning in middle school physics education classroom. American Education Research Journal, 50 (5):1020-1040.

Sage, H. (1987). Incorporating literature in ESL instruction. Englewood Cliffs. New Jersey: PrenticeHall.

Samuel, M. (1995). Using versions of literary texts to improve comprehension. TESOL Journal 4 (3): $21-23$

Schwab J. J. (1971). The Practical: Arts of the eclectic. School Review 79: 493-542.

Shinmahara, N. K. (1998). The Japanese model of professional development: Teaching a craft. Teaching and Teacher Education. 14 (5): 452-462.

Short, M. (1996). Stylistics 'upside down': Using stylistics analysis in the teaching of language and literature: In R. Carter and J. McRae. (Eds.). Language Literature and Learner. Longman London. 41.

Short, M. (1996). Exploring the language of poems, plays, and prose. Harlow: Longman Pub: 1-6.

Shulman, L. S. (1986). Those who understand: Knowledge growth in teaching. Educational Research. Vol. 15 (2): 4-14.

Shulman, L. S. (1987). Knowledge and Teaching. Foundations of the New Reforms. Harvard Educational Review. Vol. 57(1): 1-8.

Simpson, P. (1992). Teaching stylistics: analysing cohesion and narrative structure in a short story by Earnest Hemingway. Language and Literature. 1 (1): 47-67.

Simon, J. (1993). Perspective teacher's knowledge of division. Journal for Research in Mathematics Education. Vol. 24: 233-254.

Spack, R. (1985). Literature, reading, writing and ESL: Bridging the gaps. TESOL Quarterly, 19 (4): 703-725.

Subramanian, G. (2003) Linguistic pathways to the study of literature in the Malaysian ESL context. GEMA Online Journal of Language Studies, Vol. 3 (1).

Tajalarapin Sulaiman, Aminudin Hassan, Mohd. Vazatsa Sapian, Saifudin Kumar Abdullah. (2009). The level of stress among students in urban and rural secondary schools in Malaysia. European Journal of Social Sciences, Vol. 10: 179-185. 


\section{EFFECTS OF ACADEMIC QUALIFICATIONS ON MALAYSIAN ENGLISH LANGUAGE TEACHERS' SUBJECT MATTER KNOWLEDGE OF LITERARY DEVICES}

Tirosh, D. (2000). Enhancing perspective teachers' knowledge of children's conceptions: The case of divisions of fractions. Journal for Research in Mathematics Education. Vol. 31: 5-25.

Varella, G. F. (2000). Science teachers at the top of their game: What is teacher expertise? The Clearing House. ProQuest Journal. Vol. 74 (1): 43-45.

Verdonk, P. (2002). Stylistics. Oxford: Oxford University Press.

Wan Kamariah Baba. (2008). An Investigation into Teacher and Students' Attitudes Towards Literature and its use in ESL Classroom: A Case-Study at a Matriculation Centre in Malaysia. Unpublished Ph.D Thesis, University of Leicester, UK.

Wayne, A. J. \& Youngs, P. (2003). Teacher characteristics and student achievement gains: A review, Review of Educational Research. Vol. 73 (1). 89-122.

Weber, J. J. (Ed.). (1996). Stylistics reader: From Roman Jakobson to the present. London: Arnold.

Wenglinsky, H. (2000). How teaching matters. Princeton. N. J. Educational Testing Services.

Wesley, S. (1993). Job Analysis of the Knowledge Importance for Newly Licensed English Teachers. The Praxix Series.

Widdowson, H. G. (1975). Stylistics and the teaching of literature. London: Longman Pub.

Widdowson, H. G. (1992). Practical Stylistics. Oxford: Oxford University Press.

Widdowson, H. G. (1996). Stylistics: an approach to stylistics analysis. In J. J. Weber (ed.) The stylistics reader: from Roman Jakobson to the present. London, Arnold.

Wong S. K. (2003). The Road Not Taken. In G. Subramanian \& M. E. Vetamani. Teaching Literature in ESl/EFL Contexts. Kuala Lumpur Sasbadi Pub.

Van Driel, J. H, Verloop, N. \& De Voss. (1998). Developing Science teachers' pedagogical content knowledge. Journal Research on Science Teaching, 35 (6): 673-695.

Verdonk, P. (2002). Stylistics. Oxford: Oxford University Press.

\section{Contact Details of Authors}

Manickavasagar Govindasamy

c/o Faculty of Languages and Linguistics,

University of Malaya,

50603 Kuala Lumpur, Malaysia.

Email: 


\section{EFFECTS OF ACADEMIC QUALIFICATIONS ON MALAYSIAN ENGLISH LANGUAGE TEACHERS' SUBJECT MATTER KNOWLEDGE OF LITERARY DEVICES}

Jariah Mohd. Jan

Faculty of Languages and Linguistics,

University of Malaya,

50603 Kuala Lumpur, Malaysia.

Email: jariah@um.edu.my

\section{Biodata}

Manickavasagar Govindasamy is currently a Ph.D student at the Faculty of Languages and Linguistics, University of Malaya and holds a MESL degree. He has vast experience in the teaching of the English language and literature. His area of research is mainly in the teaching of literature.

Jariah Mohd. Jan is an Associate Professor in the Department of English Language, Faculty of Languages and Linguistics, University of Malaya. Her main research interests include gender and power issues in language, pragmatics, discourse and society, social networks and workplace discourse. 